\title{
Community structure of Echinoderms in seagrass beds of Pacitan beaches, East Java, Indonesia
}

\author{
FARID KAMAL MUZAKI ${ }^{1, \bullet}$, EDWIN SETIAWAN ${ }^{1, \bullet \bullet}$, GHULAM FATHIR AUTHAR INSANY ${ }^{1}$, \\ NURUL KUSUMA DEWI ${ }^{2}$, IWENDA BELLA SUBAGIO \\ ${ }^{1}$ Department of Biology, Faculty of Science, Institut Teknologi Sepuluh Nopember. Jl. Arief Rahman Hakim - Surabaya 60111, East Java, Indonesia. \\ Tel./fax.: +62-31-5963857, ^email: rm_faridkm@bio.its.ac.id; vvedwin@bio.its.ac.id. \\ ${ }^{2}$ Department of Biology Education, Faculty of Teacher Training and Education, Universitas PGRI Madiun. J1. Setiabudi 85 Kartoharjo, Madiun 63118, \\ East Java, Indonesia \\ ${ }^{3}$ Department of Biology Education, Faculty of Mathematics and Natural Science, IKIP PGRI Jember. Jl. Jawa 10, Sumbersari, Jember 68121, East Java, \\ Indonesia
}

Manuscript received: 19 March 2019. Revision accepted: 1 June 2019.

\begin{abstract}
Muzaki FK, Setiawan E, Insany GFA, Dewi NK, Subagio IB. 2019. Community structure of Echinoderms in seagrass beds of Pacitan beaches, East Java, Indonesia. Biodiversitas 20: 1787-1793. In this study, we attempt to access diversity and community structure of Echinoderms on seagrass beds in each three belt transect (width $2 \mathrm{~m}$, length $100 \mathrm{~m}$ ) in Tawang and Pidakan beaches, Pacitan, East Java, Java. Observed parameters were species richness, composition, and abundance, as well as diversity indices: ShannonWiener's diversity index (H'), Simpson's dominance index (D) and Pielou's evenness index (J). At the end of the study, we identified one species of sea star (Asteroidea), seven species of brittle stars (Ophiuroidea), ten species of sea cucumbers (Holothuroidea) andnine species of sea urchins (Echinoidea). The most dominant species were Ophiocoma dentata (F. Ophiocomidae), Diadema setosum (F. Diadematiidae), Ophiomastix annulosa (F. Ophiocomidae) and Echinometra mathaei (F. Echinometridae). Value of H' ranged from 0.538 to 1.252 in Tawang and 1.041 to 1.704 in Pidakan; which showing higher species richness and diversity in Pidakan. Echinoderm in the study area was not evenly distributed; $D$. setosum was very dominant in Tawang beach, while those three other species were more common in Pidakan. Furthermore, most of Holothuroid and Ophiuroid were found only in Pidakan which have relatively more complex habitat.
\end{abstract}

Keywords: Diversity, Echinoderms, Pidakan beach, seagrass bed, Tawang beach

\section{INTRODUCTION}

Biodiversity assessment of marine ecosystem is very useful to understand the ecological patterns, ecosystem function and conservation management (Setyastuti et al 2018) as well as to detects, monitor, measures and estimates the fluctuation of diversity and the implications of its changes to the ecosystem function (Iken et al. 2010; Wheeler et al. 2012); for examples are the study of seagrass ecosystem by Daby (2003), Bishop (2008), HerreraSilveira et al. (2010), Norldund and Gulstrom (2013), Siddiq et al. (2016) and Furqan and Muzaki (2018).

Seagrass beds are providing habitat function, food source and shelter for the marine organism (Azkab 2001) and stable seagrass ecosystems are controlled by animalplant interactions (Heck and Valentine 2007). The complexity of multispecies interactions in seagrass beds between fauna associations with seagrasses will support the sustainability of ecosystems (Lundberg and Moberg 2003). One group of animal living in seagrass beds are echinoderms, which utilize the seagrass beds as the food source, shelter, nursery, and spawning (Vaitilingon 2003; Dissanayake and Gunnar 2012; Vonk et al. 2009; Bos et al. 2011). In the seagrass system, echinoderms such as Holothuroids are positive as a major bioturbator because they can increase the productivity and through their excretory physiology, they also can increase local nutrients
(Uthicke 2001; Wolkenhauer et al. 2010; Jamieson et al. 2011; Costa et al. 2014; Wolfe and Byrne 2017) and potential to help buffer the effects of ocean acidification (Schneider et al. 2011; Schneider et al. 2013; Wolfe and Byrne 2017). Echinoids has an important role in controlling the algal cover on hard substrates, they directly impact the seagrass and algae for releasing and recycling nutrients obtained from food in the form of microalgae, bacteria, and organic detritus in sediments (Moriarty et al. 1985; Wiedemeyer 1992), while asteroids also play an important role in maintaining community structures as predators (Gaymer et al. 2004; Verling et al. 2003).

In the southern coast of Pacitan, East Java, seagrass beds occurred in almost all of the coastline; particularly in Tawang which is a traditional port for coastal fisheries, and Pidakan which is a location for tourism. In these areas, the data on marine biodiversity is still lacking; and this study is aimed to access diversity and community structure of echinoderms in the area. Thus, data obtained from this study can be used as a baseline for local coastal management.

\section{MATERIALS AND METHODS}

\section{Study area}

The research takes place in the area of Tawang and Pidakan beaches in the coastal area of Pacitan, East Java, 
Indonesia (Figure 1). Tawang beach located at $08^{\circ} 15^{\prime} 39.50^{\prime \prime} \mathrm{S}$ and $111^{\circ} 17^{\prime} 18.90^{\prime \prime} \mathrm{E}$ whereas Pidakan beach is located at $08^{\circ} 15^{\prime} 19.50^{\prime \prime} \mathrm{S}$ and $111^{\circ} 14^{\prime} 29.50^{\prime \prime} \mathrm{E}$. Tawang beach situated in a bay surrounded with hills, therefore relatively sheltered or protected from huge wave and the strong current of the Indian ocean. Bottom substrates composed by a mixture of sand and silt (in transect \#1 and \#2), with some boulders and colonies of massive and submassive corals scattered in the seaward margin of the seagrass bed. Rocky substrates existed mainly in the western part of the bay, which transect \#3 was established. In all transects, seagrass vegetation dominated by turtle grass (Thalassia hemprichii) and spoon grass (Halophila ovalis). Many shallow tide pools (depth less than $20 \mathrm{~cm}$ ) occurred in the area in low tide, as presented in Figure 2.

The Pidakan site has different and relatively more complex habitat characteristics compare to Tawang. In Pidakan, the beach faces directly to the Indian ocean which has huge waves (Figure 3) and stronger current. The substrates are coarser; transect \#1 and \#2 dominated by coarse sand and rubble or gravel while transect \#3 dominated by rock, gravel, and rubble. The seagrass bed dominated solely by turtle grass; larger and deeper tide pools (variable depth from 10 to $40 \mathrm{~cm}$ ) occurred at low tide, with many boulders and coral colonies from variable size are scattered all over the area.

\section{Environmental variables}

Ambient parameters measured in situ including salinity, water temperature, alkalinity or $\mathrm{pH}$ levels, level of dissolved oxygen (DO), as well as seagrass density and percent cover. Seagrass density and cover measurement followed the protocol by English et al. (1994). Transect for seagrass vegetation analysis used the same transect for echinoderms observation. A $100 \mathrm{~m}$ transect was laid perpendicular to the shoreline at each station during low tide. Sampling unit or quadrat for seagrass vegetation analysis is $1 \times 1 \mathrm{~m}$, and we made 20 quadrats per transect.

Seagrass density calculation:

$$
D i=\frac{N i}{A}
$$

$D i$ is the density of the $i$-th species per $\mathrm{m}^{2}, N i$ is an abundance of the $i$-th species, and $A$ is total sampling area in $\mathrm{m}^{2}$. Density category for seagrass was referred to Widyorini et al. (2012) which grouping seagrass density onto three groups; low density $\left(<106\right.$ ind. $\left./ \mathrm{m}^{2}\right)$, moderate density (between 106 to 355 ind. $/ \mathrm{m}^{2}$ or 244 ind. $/ \mathrm{m}^{2}$ in average) and high density (>355 ind.$\left./ \mathrm{m}^{2}\right)$.

Seagrass cover calculation:

$$
C i=\frac{\Sigma(M i \times f i)}{\Sigma f i}
$$

$C i$ is the density of the $i$-th species per $\mathrm{m}^{2}, M i$ is the percentage of midpoint class of the $i$-th species and $f$ is frequencies (number of grids or sectors with similar dominance class (English et al. 1994).

\section{Echinoderms observation}

The research was conducted from May to September 2018. Three units of belt transect (each with $2 \mathrm{~m}$ width and $100 \mathrm{~m}$ length; total area $200 \mathrm{~m}^{2}$ ) were established on seagrass beds in each location, perpendicular to the shoreline. Sampling was conducted during the low tide to get a better view while inventorize the echinoderms benthic community. The observers identify (to the level of species, if possible) and count every individual of echinoderms inside the transect. Some individuals were also collected and preserved in $70 \%$ alcohol for further examination in the laboratory.

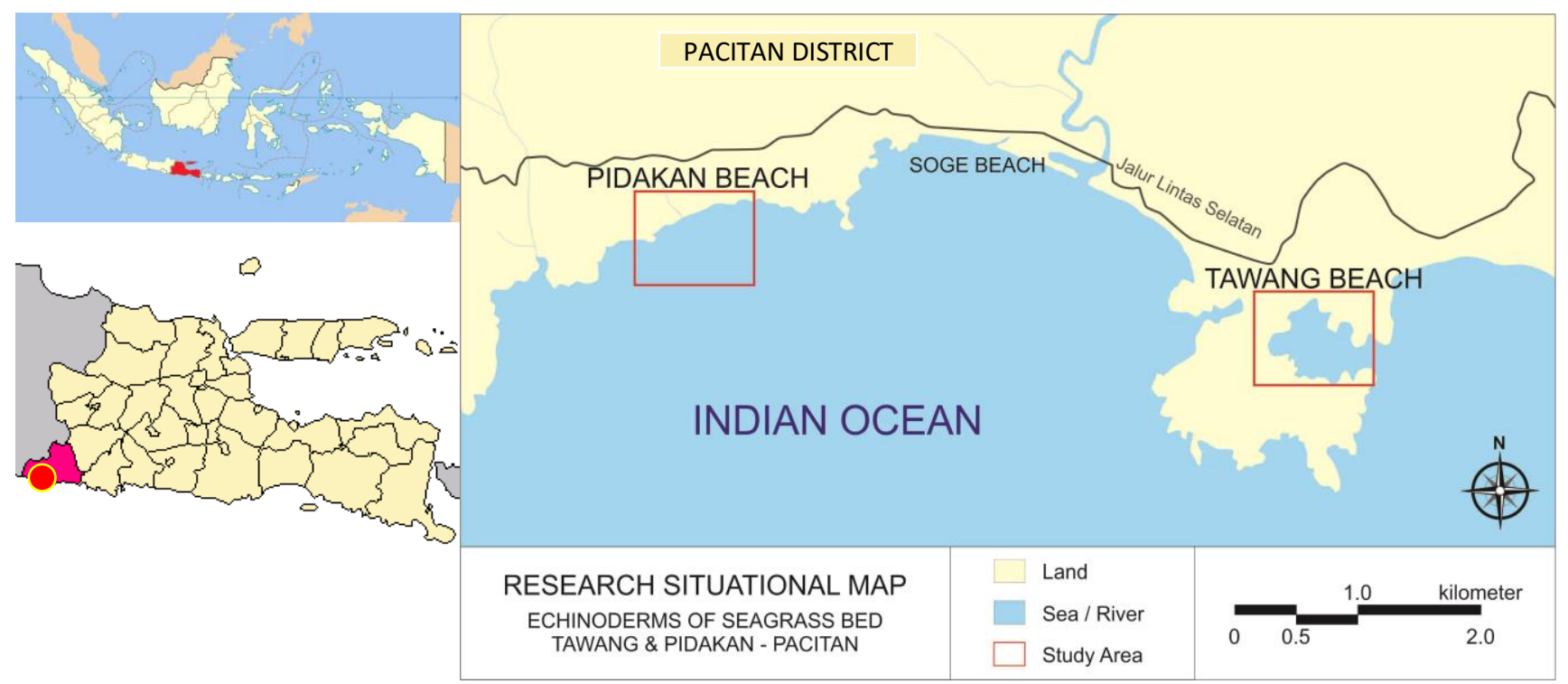

Figure 1. Study sites in Tawang and Pidakan beach, coastal area of Pacitan District, East Java, Indonesia 

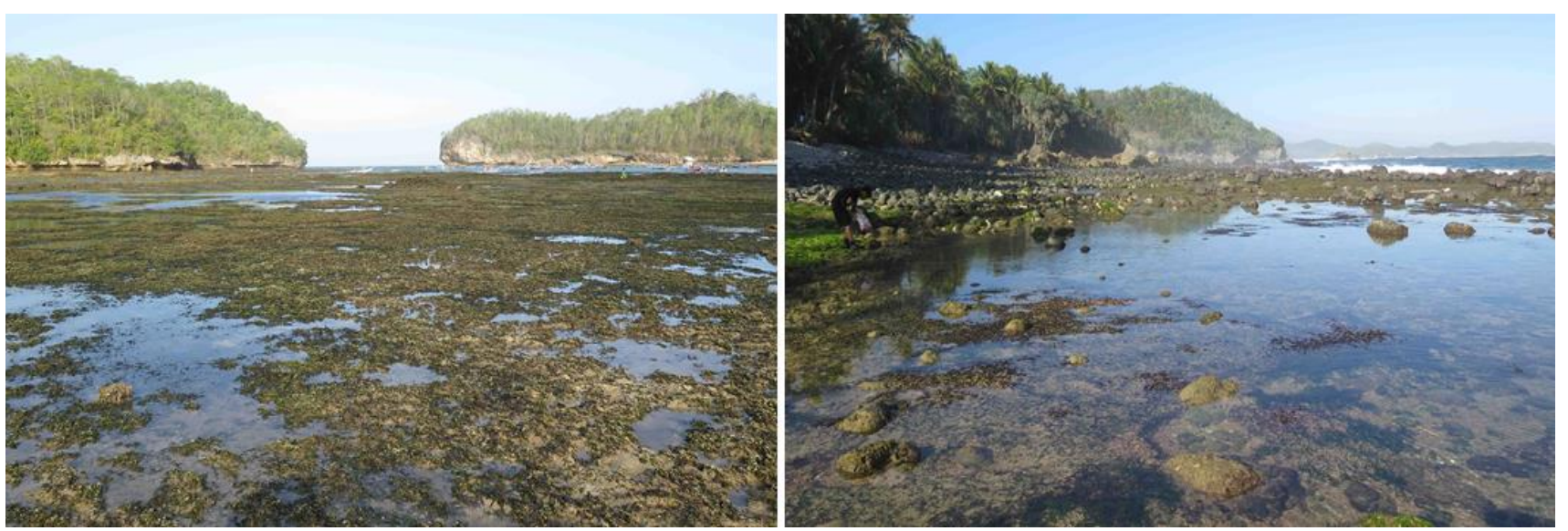

Figure 2. Seagrass bed of Tawang (left) and Pidakan (right) beach at low tide of Pacitan District, East Java, Indonesia

Identification to the level of species refers to Colin and Arneson (1995); Conand (1998); Jontila et al. (2014); Llacuna et al. (2016); Setyastuti et al. (2018); and other relevant and representative literature.

\section{Data analysis}

The data analyzed by the descriptive-quantitative approach. Species diversity was indicated by species richness and equitability of individuals among species (Uneputty et al. 2017). Species richness represented as a number of species in a particular location and period; while diversity counted with Shannon-Wiener index counted as follows:

$$
H^{n}=-\Sigma\left[\left(\frac{n i}{N}\right) \times \ln \left(\frac{n i}{N}\right)\right]
$$

$H^{\prime}$ is Shannon-Wiener diversity index; $n i$ is an individual number of the abundance of species-i and $N$ is the total number of individual in the community (Magurran 1991; Dhahiyat et al. 2003). Value of H' then used to determine the level of diversity of the community; based on the certain standard as shown in Table 1.

The diversity is also represented by Simpson's index of dominance (D) and Pielou's species evenness index (J) as follows;

$$
\begin{aligned}
& D=\Sigma\left(\frac{n i}{N}\right)^{2} \\
& l=\frac{H^{\prime}}{\ln (S)}
\end{aligned}
$$

$D$ is the value of Simpson's dominance index, and $J$ is the value of Pielou's evenness index; $n i$ is an individual number of the abundance of species-i and $N$ is a total number of individual in community; $H^{\prime}$ is Shannon-Wiener diversity index and $S$ is a number of species occurred in a given area. The value of $D$ ranged from 0.00 to 1.00 (Krebs 1999).
Table 1. Criteria of diversity (Krebs 1999)

\begin{tabular}{ll}
\hline Criteria & Value of H' \\
\hline High diversity & $\mathrm{H}^{\prime}>3.22$ \\
Moderate diversity & $1.00 \leq \mathrm{H}^{\prime} \leq 3.22$ \\
Low diversity & $1.00<\mathrm{H}^{\prime}$ \\
\hline
\end{tabular}

\section{RESULTS AND DISCUSSION}

\section{Environmental variables}

The average value of the environmental variable and quality standard for the marine organism are available in Table 2. Based on Table 2, all of the environmental variables are still in the range of quality standard for marine life, based on the Ministry of Environment of Republic of Indonesia (2004). Azis (1996) stated that in general, a suitable temperature for echinoderms is $28-30^{\circ} \mathrm{C}$; whereas echinoderms tolerance for salinity is $25-35 \%$ o (Roller and Stickle 1985). Thus, it can be concluded that environmental factors in seagrass bed of Tawang and Pidakan beach are still supporting for the life of the biota within.

As mentioned earlier, seagrass vegetation in Tawang dominated by turtle grass and spoon grass with the total density of $142.67 \pm 22.81$ individual $/ \mathrm{m}^{2}$ and higher than in Pidakan $\left(126 \pm 55.83\right.$ individual $\left./ \mathrm{m}^{2}\right)$. Similarly, life seagrass cover in Tawang was higher compared to Pidakan $(31.44 \pm 3.65 \%$ versus $19.69 \pm 3.65$, respectively). In both locations, seagrass density is considered 'moderate' (Widyorini et al. 2012). Percent cover and density of seagrass beds will affect the magnitude of the ecological benefits of seagrass beds. Seagrass beds provide a variety of functions such as habitat for organisms that cannot live in the sea bottom without vegetation, leaf canopies and rhizome; and seagrass roots providing additional attachments for epiphytic organisms. In addition, the threedimensional structure of seagrasses creates a hiding place 
Table 2. Results of environmental variables measurement

\begin{tabular}{|c|c|c|c|}
\hline \multirow{2}{*}{ Parameter } & \multicolumn{2}{|c|}{ Location } & \multirow{2}{*}{ QS } \\
\hline & Tawang & Pidakan & \\
\hline Salinity (\%o) & $32.5 \pm 0.5$ & $33.17 \pm 0.29$ & $33-34$ \\
\hline Temperature $\left({ }^{0} \mathrm{C}\right)$ & $28.73 \pm 0.25$ & $28.23 \pm 0.25$ & $28-32$ \\
\hline Dissolved oxygen (ppm) & $7.44 \pm 1.34$ & $7.90 \pm 1.28$ & $>5$ \\
\hline $\mathrm{pH}$ & $7.56 \pm 0.92$ & $7.82 \pm 0.31$ & $7-8.5$ \\
\hline Seagrass species & $\begin{array}{c}\text { Thalassia hemprichii } \\
\text { Halophila ovalis }\end{array}$ & Thalassia hemprichii & NA \\
\hline Seagrass density (ind./m²) & $142.67 \pm 22.81$ & $126 \pm 55.83$ & NA \\
\hline Seagrass cover $\left(\% / \mathrm{m}^{2}\right)$ & $31.44 \pm 3.65$ & $19.69 \pm 3.65$ & NA \\
\hline
\end{tabular}

Note: QS. quality standard based on Appendix III of KepMen LH No 51 2004; NA. data not available

to avoid predation that causes abundance and diversity of fauna and flora living in seagrass beds is consistently higher than in non-vegetated seagrass regions (Borum et al. 2004). A study by Pratiwi (2010) revealed that there was a correlation between seagrass species richness and density to the benthic organism; higher seagrass species richness and density will result in higher associated benthic species richness.

\section{Species richness, composition, and abundance of echinoderms}

In general, 27 species of Echinoderms were identified, composed by single species of Asteroidea (starfish), seven species of Ophiuroidea (brittle star), ten species of Holothuroidea (sea cucumber) and nine species of Echinoidea (sea urchin). Each location has different dominant species, probably caused by a relatively different physical and biological condition in each location. In Tawang, the echinoderm community composed of 18 species (Figure 3) and dominated by sea urchin Diadema setosum (F. Diadematiidae) by the relative abundance of $79.62 \%$ from the total population in the area. The second dominating species is sea urchin Tripneustes gratilla (F. Toxopneustidae) by $7.32 \%$ from the total population. Most of the echinoderms in Tawang found inside shallow tide pool that scattered over the seagrass bed. Two species of sea cucumber, Holothuria atra and H. leucospilota (with a relatively lower density) found only in transect \#3 which is sandier and have many rocky substrata.

These findings are similar to the research results of Supono and Arbi (2010) in Kema, North Sulawesi where $D$. setosum, $T$. gratilla and $D$. savignyi were the dominant echinoderms found in a seagrass bed. The high density of $D$. setosum and T. gratilla in Tawang is probably due to their nature. In the seagrass system, D. setosum feed on algae, crustaceans, and foraminifera (Lawrence 2007; Karleskint et al. 2010) and may act as keystone species (Jenarkoff et al. 1996). Species of T. gratilla usually found in an area with a high density of seagrass where they feed on the fresh stand of turtle grass (Klumpp et al. 1993). Vonk et al. (2009) stated that T. gratilla consume at least $26 \%$ of the net productivity of turtle grass, as well as seagrass Halodule uninervis and Cymodocea rotundata.
Echinoderm species richness in Pidakan was higher than Tawang, with at least 23 species were identified (Figure 3 and 4). In contrast, fewer individual of $D$. setosum and T. gratilla found in Pidakan and seems to be replaced by Echinometra mathaei (F. Echinometridae). The most dominant species in Pidakan are brittle star Ophiocoma dentata (F. Ophiocomidae, 52.50\%) and Ophiomastix annulosa (F. Ophiocomidae, 17.46\%); followed by sea urchin E. mathaei $(14.41 \%)$. Most of $O$. dentata and $E$. mathaei found in transect \#3 while most of $O$. annulosa abundant in transect \#1 and \#2. Similar to Tawang, most echinoderms in Pidakan were also found in tide pools (which are larger and deeper than in Tawang), especially beneath the massive coral colonies, rocks or boulders.

Some species of echinoderms are found only in Tawang, i.e. Protoreaster nodosus (F. Oreasteridae), Brissus latecarinatus (F. Brissidae) and Laganum laganum (F. Laganidae); whereas some other could only be found in Pidakan, i.e., Ophiolepis superba (F. Ophiolepididae), Macrophiothrix longipeda (F. Ophiotrichidae), Actinopyga echinites (F. Holothuriidae), four species of Holothuria ( $H$. edulis, H. hilla, H. pervicax, and H. scabra, $\mathrm{F}$. Holothuriidae) and Heterocentrotus trigonarius (F. Echinometridae).

It is still unclear why sea cucumber $H$. atra was found only in low density. In many publications (i.e., Slater et al. 2011; Costa et al. 2013 and Furqon and Muzaki 2018), this species tends to be found in high density in an area with higher organic matter content. In this study, we have not analyzed the organic content in the sediment of the seagrass bed; however, denser stands of seagrass usually correlated with higher organic content. In Tawang which have denser seagrass, 21 individuals of $H$. atra counted; while in Pidakan (with lower seagrass density), we found only five individuals. Seastar, P. nodosus was found only in Tawang which have a finer substrata and higher seagrass density and cover. Food habits for this species are seagrass, detritus, and macroalgae (Susetiono 2007) which abundant in Tawang. 


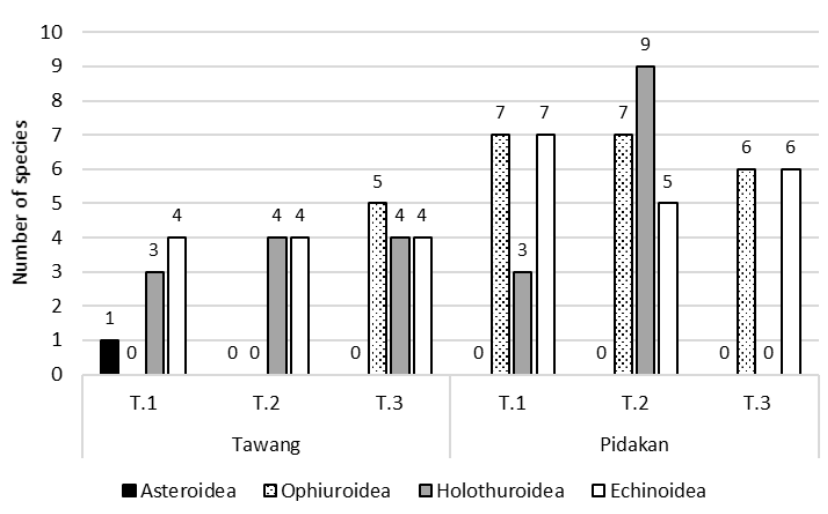

Figure 3. Species richness of echinoderms (from each subclass) in Tawang and Pidakan beach. Pidakan seagrass bed has higher species richness ( 23 species, or 12 to 21 species at each transect) compared to Tawang (18 species, or 8 to 13 species at each transect)

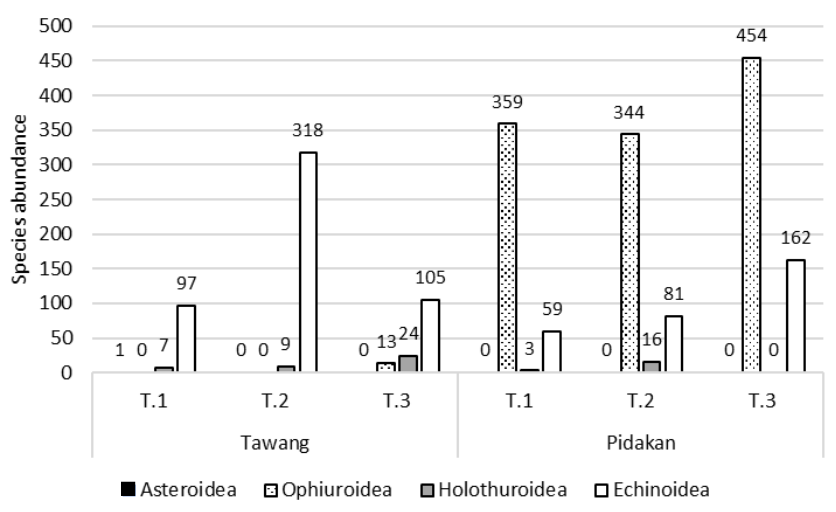

Figure 4. Species abundance of Echinoderms (from each subclass) in Tawang and Pidakan beach. Pidakan seagrass bed has a higher abundance (from 420 to 616 individual at each transect) compared to Tawang (from 106 to 327 individual at each transect). The most abundant Echinoderms in Tawang is Echinoidea (sea urchin), while in Pidakan dominated by Ophiuroidea (brittle star) and Echinoidea

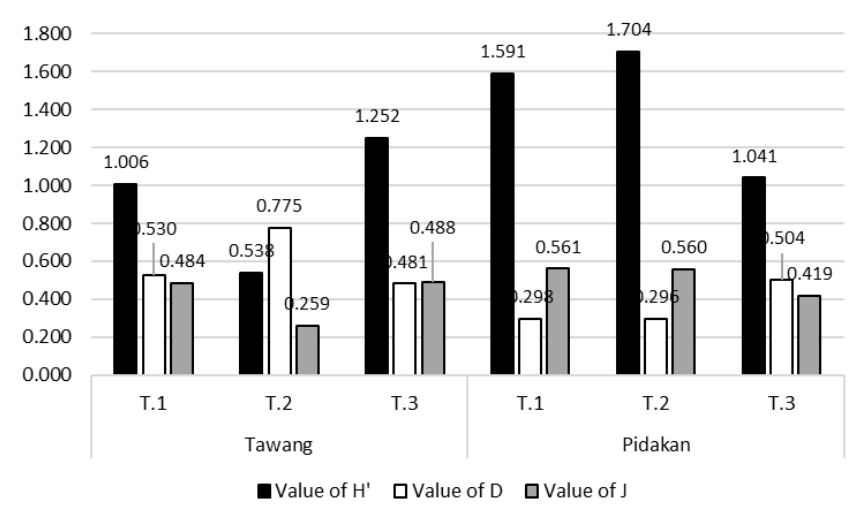

Figure 5. Value of ShannonWiener's diversity index (H'), Simpson's dominance index (D) and Pielou's species evenness index (J) in the study area. The highest diversity is in Pidakan transect \#2 and \#1, the lowest is in Tawang transect \#2 and \#1, respectively
Most of ophiuroids species were found only in Pidakan; this is probably because of the bottom in the location which composed by sand (coarse to fine sand). Regarding to Aziz (1995), the ophiuroids prefer soft bottom substrata that enabling them to bury themselves and hide during low tide or when the light intensity is high.

\section{Species diversity}

The value of Shannon-Wiener's diversity index ( $\left.\mathrm{H}^{\prime}\right)$ in Tawang ranged from 0.538 to 1.252 , and from 1.041 to 1.704 in Pidakan as depicted in Figure 5. The higher value of $\mathrm{H}^{\prime}$ in Pidakan is caused by the highest number of species (species richness) and relatively more even abundance among species. The highest value of $\mathrm{H}^{\prime}$ is in transect \#2 and \#1 of Pidakan, which have the highest species richness (21 species and 17 species, respectively). The lower diversity values in Tawang and Pidakan transect \#3 appear caused by lower species richness and dominance of one or several species in those locations or transects. For example, brittle star $O$. dentata is quite dominant in Pidakan transect \#3; and sea urchin D. setosum is very dominant in all transect in Tawang.

The difference in diversity between those two locations probably also caused by the magnitude of anthropogenic activities. This factor was not accounted nor measured in this study; however, we visually noted that anthropogenic factors in Tawang were relatively higher than Pidakan. As described earlier, the area of Tawang become a traditional fishing port where the fishermen docked their boats directly in the seagrass bed. As an implication, there must be a high level of fishermen trampling and boat traffic in the area. A different situation occurred in Pidakan where the seagrass bed was seldom trampled by the tourist, although some traditional fishermen still accessing the area at the ebb tide to gather invertebrates and catch small fish.

Anthropogenic activities (including trampling, tourism or harvesting marine biota) in seagrass areas have been reported to have a negative impact on seagrass and inhabiting fauna as reported by Daby (2003); Bishop (2008); Herrera-Silveira et al. (2010); and Norldund and Gulstrom (2013). There have been no or limited studies on the direct impact of trampling on echinoderm, but lower species richness of echinoderm could be related to the decrease of food source in an area with higher anthropogenic activities. Anthropogenic activity had been reported to causing a decrease of bivalves, gastropods and crustaceans (Schlacher et al. 2014) or polychaetes (Casu et al. 2006a) which are the food source for many echinoderms.

Species diversity likely contributes to the stability of the community; therefore, stable communities will also often have high values of species diversity. In general, the value of $\mathrm{H}^{\prime}$ documented in the echinoderms communities we studied in our area was considered as 'low' to 'moderate' (H' 0.0538-1.704) (Oktavianti et al. 2014).

Level of diversity can also be described by the value of Pielou's evenness index (J) and Simpson's dominance index (D). Locations or transects with a higher value of $\mathrm{H}^{\text {' }}$ have a relatively lower value of $\mathrm{D}$. In contrast, higher value of $\mathrm{H}^{\prime}$ is usually followed by a higher value of J. For 
example, among locations and transects, transect \#1 and \#2 in Pidakan have H' value of 1.591 and 1.704 whereas value of D are 0.298 and 0.296 (or lowest among other) while the value of $\mathrm{J}$ are 0.561 or 0.560 or highest among others; showing more evenly distribution of population in those transects. It can be concluded that higher value of $\mathrm{H}^{\prime}$ will be achieved if there are more species (high species richness) and population of each species is evenly distributed, or when there are no one or several species that are very dominating in the community.

\section{ACKNOWLEDGMENTS}

We thank Institute of Research and Community Service (LPPM) of Institut Teknologi Sepuluh Nopember, Surabaya for the local grant schemed as PEKERTI to funding this research. We also thank local communities in Tawang and Pidakan beaches for providing valuable information regarding the research.

\section{REFERENCES}

Aziz A. 1995. Beberapa catatan bintang mengular (Ophiuroidea) sebagai biota bentik. Oseana 16 (1): 13-22. [Indonesian]

Azkab MH. 2001. Penggunaan inderaja pada padang lamun. Oseana 16 (2): 9-16. [Indonesian]

Bishop MJ. 2008. Displacement of epifauna from seagrass blades by boat wake. J Exp Mar Biol Ecol 354: 111-118.

Borum J, Duarte CM, Krause-Jensen D, Greve TM. 2004. European Seagrasses: An Introduction to Monitoring and Management. The EU Project Monitoring and Managing of European Seagrasses (M\&MS), Brussel.

Bos AR, Gumanao GS, Katwijk MM, Mueller B, Saceda MM, Tejada RLP. 2011. Ontogenetic habitat shift, population growth and burrowing behaviour of the Indo-Pacific beach star, Archaster typicus (Echinodermata: Asteroidea). Mar Biol 158 (3): 639-648.

Casu D, Ceccherelli G, Curini-Galletti M, Castelli A. 2006. Short-term effects of experimental trampling on polychaetes of a rocky intertidal substratum (Asinara Island MPA, NW Mediterranean). Sci Mar 70 179-186.

Colin PL, Arneson C. 1995. Tropical Pacific Invertebrates: A Field Guide to the Marine Invertebrates Occurring on Tropical Pacific Coral Reefs, Seagrass Beds and Mangroves. Coral Reef Press, Beverly Hills, California, U.S.A.

Conand C. 1998. Holothurians. In: Carpenter KE, Niem VH (eds) The Living Marine Resources of Western Central Pacific, Volume 2 : Cephalopods, Crustaceans, Holothurians and Sharks. The Food and Agricultural Organization of the United Nations, Rome.

Costa V, Mazzola A, Vizzini S. 2014. Holothuria tubulosa Gmelin, 1791 (Holothuroidea, Echinodermata) enhances organic matter recycling in Posidonia oceanica meadows. J Exp Mar Biol Ecol 461: 226-232.

Daby D. 2003. Effects of seagrass bed removal for tourism purposes in a Mauritian bay. Environ Pollut 125: 313-324.

Dhahiyat Y, Sinuhaji D, Hamdani H. 2003. Struktur komunitas ikan karang di daerah transplantasi karang Pulau Pari, Kepulauan Seribu. Jurnal Ikhtiologi Indonesia 3. [Indonesian]

Dissanayake DCT, Stefansson G. 2012. Habitat preference of sea cucumbers: Holothuria atra and Holothuria edulis in the coastal waters of Sri Lanka. J Mar Biol Assoc UK 92 (3): 581-590.

English S, Wilkinson C, Baker V. 1994. Survey Manual for Tropical Marine Research. ASEAN-Australia Marine Science Project. Australian Institute of Marine Science, Townsville.

Furqon F, FK. Muzaki. 2018. Studi Komunitas Echinodermata pada Padang Lamun Pantai Bama dan Kajang, Taman Nasional Baluran, Situbondo, Jawa Timur. Departemen Biologi, Institut Teknologi Sepuluh Nopember (ITS), Surabaya. [Indonesian]
Gaymer CF, Dutil C, Himmelman JH. 2004. Prey selection and predatory impact of four major sea stars on a soft bottom subtidal community. J Exp Mar Biol Ecol 313 (2): 353-374.

Heck Jr. KL, Valentine JF. 2007. The primacy of top-down effects in shallow benthic ecosystems. Estuar Coasts 30 (3): 371-381.

Herreira-Silveira JA, Cebrian J, Hauxwell J, Ramirez-Ramirez J, Ralph P. 2010. Evidence of negative impacts of ecological tourism on turtlegrass (Thalassia testudinum) beds in a marine protected area of the Mexican Caribbean. AquatEcol 44: 23-31

Iken K, Konar B, Benedetti-Cecchi L, Cruz-Motta JJ, Knowlton A. 2010. Large-scale spatial distribution patterns of echinoderms in nearshore rocky habitat. Plos ONE 5 (11).

Jamieson AJ, Gebruk A, Fujii T, Solan M. 2011. Functional effects of the hadal sea cucumber Elpidia atakama (Echinodermata: Holothuroidea, Elasipodida) reflect small-scale patterns of resource availability. Mar Biol 158: 2695-2703.

Jontila JBS, Balisco RAT, Matillano J. A. 2014. The sea cucumbers (Holothuroidea) of Palawan, Philippines. AACL Bioflux 7 (3): 194206.

Karleskint Jr G, Turner R, Small Jr JW. 2010. Introduction to Marine Biology, 3rd Edition. Brooks/Cole, Belmont, CA.

Klumpp DW, Salita-Espinosa JT, Fortes MD. 1993. Feeding ecology and trophies role of sea urchins in a tropical seagrass community. Aquat Bot 45: 205-229.

Krebs CJ. 1999. Ecological Methodology. 2nd ed. Benjamin Cummings, Menlo Park, CA.

Lawrence JM. 2007. Edible Sea Urchins: Biology and Ecology, Volume 38 (Developments in Aquaculture and Fisheries Science) 2nd Edition Elsevier Science, Amsterdam.

Llacuna MEJ, Walag APM., Villaluz EA. 2016. Diversity and dispersion patterns of echinoderms in Babanlagan, Talisayan, Misamis Oriental, Philippines. Environ Exp Biol 14: 213-217.

Lundberg J, Moberg F. 2003. Mobile link organisms and ecosystem functioning: implications for ecosystem resilience and management. Ecosystems 6: 87-98.

Magurran AE. 1991. Ecological Diversity and Its Measurement. Chapman and Hall, London.

Ministry of Environment of Republic of Indonesia, Resolution no 51 year 2004, Appendix III. [Indonesian]

Moriarty DJW, Pollard PC, Hunt WG, Moriarty CM, Wassenberg TJ. 1985. Productivity of bacteria and microalgae and the effect of grazing by holothurians in sediments on a coral reef flat. Mar Biol 85: 293-300.

Pratiwi R. 2010. Asosiasi krustasea di ekosistem padang lamun perairan Teluk Lampung. Ilmu Kelautan 15 (2): 66-76. [Indonesian]

Roller RA, Stickle WB. 1985. Effects of salinity on larval tolerance and early development rates of four species of echinoderms. Can J Zool 63: 1531-1538.

Schneider K, Silverman J, Kravitz B, Rivlin T, Schneider-Mor A, Barbosa S, Byrne M, Caldeira K. 2013. Inorganic carbon turnover caused by digestion of carbonate sands and metabolic activity of holothurians. Estuar Coastal Shelf Sci 133: 217-223.

Schneider K, Silverman J, Woolsey E, Eriksson H, Byrne M, Caldeira K. 2011. Potential influence of aspidochirotid sea cucumbers on coral reef $\mathrm{CaCO}$ budget: a case study at one tree reef. J Geophys Res 116: G04032.

Setyastuti A, Purbiantoro W, Hadiyanto. 2018. Spatial distribution of echinoderms in littoral area of Ambon Island, Eastern Indonesia. Biodiversitas 19 (5): 1919-1925.

Setyastuti A, Wirawati A, Iswari MY. 2018. Spatial distribution of echinoderms in littoral area of Ambon Island, Eastern Indonesia. Biodiversitas 19 (2): 646-652

Siddiq AM., Atmowidi T, Qayim I. 2016. The diversity and distribution of Holothuroidea in shallow waters of Baluran National Park, Indonesia. Biodiversitas 17 (1): 55-60.

Slater MJ, Jeffs AG. 2010. Do benthic sediment characteristics explain the distribution of juveniles of the deposit-feeding sea cucumber Australostichopus mollis. J Sea Res 64: 241-249.

Supono, Arbi UY. 2010. Struktur komunitas Ekhinodermata di padang lamun perairan Kema, Sulawesi Utara. Oseanologi dan Limnologi di Indonesia 36 (3): 329-342. [Indonesian]

Susetiono. 2007. Lamun dan Fauna Teluk Kuta, Pulau Lombok. Pusat Penelitian Oseanografi - LIPI, Jakarta. [Indonesian]

Uneputty PA, Tuapattinaja MA, Pattikawa JA. 2017. Density and diversity of echinoderms in seagrass bed, Baguala Bay, Maluku, Eastern Indonesia. Int J Fish Aquat Stud5 (3): 311-315. 
Uthicke S, Klumpp DW. 1998. Microphytobenthos community production at a near-shore coral reef: seasonal variation and response to ammonium recycled by holothurians. Mar Ecol Prog Ser 169: 1-11.

Uthicke S. 2001. Nutrient regeneration by abundant coral reef holothurians. J Exp Mar Biol Ecol 265: 153-170.

Vaïtilingon D, Rasolofonirina R, Jangoux M. 2003. Feeding preferences, seasonal gut repletion indices, and diel feeding patterns of the sea urchin Tripneustes gratilla (Echinodermata: Echinoidea) on a coastal habitat off Toliara (Madagascar). Mar Biol 143 (3): 451-558.

Verling EA, Croock C, Barnes DKA, Harisson. 2003. Structural dynamics of sea star in rocky intertidal food chains: predator risk cues alter prey feeding rates. Ecology 84: 629-640.

Vonk JA, Christiansen MJA, Stapel J. 2009. Abundance, edge effect, and seasonality of fauna in mixed-species seagrass meadows in southwest Sulawesi, Indonesia. Mar Biol Res 10 (3): 282-291.

Wheeler QD, Knapp S, Stevenson DW, Stevenson J, Blum SD, Boom BM, Buizer JL, Decarvalho MR, Cibrian A, Donoghue MJ, Doyle V, Graham $\mathrm{CH}$, Graves P, Graves SJ, Guralnick RP, Hamilton AL, Borisy GG, Gerson E. M., Hanken J, Lipscomb DL, Lovejoy TE Miller H, Miller JS, Naeem S, Novacek MJ, Page LM, Platnick NI, Porter-Morgan H, Raven PH, Solis MA, Aldecasas AG, Van Der
Leeuw S, Vasco A, Vermeulen N, Vogel J, Walls R. L., Wilson EO, Woolley JB. 2012. Mapping the biosphere: exploring species to understand the origin, organization, and sustainability of biodiversity. Syst Biodivers 10: 1-20.

Widyorini N, Ruswahyuni, Sulardiono B, Suprapto D, Suryanto A. 2012. Kajian Kondisi Ekosistem Pulau Panjang untuk Kegiatan Perikanan di Kabupaten Jepara Provinsi Jawa Tengah. Universitas Diponegoro, Semarang. [Indonesian]

Wiedemeyer WL. 1992. Feeding behavior of two tropical Holothurians, Holothuria scabra and Holoturia atra, from Okinawa, Japan. In: Richmond RH (Ed.) Proceedings of the 7th International Coral Reef Symposium Volume 2: 853-860. University of Guam Press, Mangilao, Guam.

Wolfe K, Byrne M. 2017. Biology and ecology of the vulnerable holothuroid, Stichopus herrmanni, on a high-latitude coral reef on the Great Barrier Reef. Coral Reefs 36: 1143-1156.

Wolkenhauer SM, Uthicke S, Burridge C, Skewes T, Pitcher R. 2010. The ecological role of Holothuria scabra (Echinodermata: Holothuroidea) within subtropical seagrass beds. J Mar Biol Assoc UK 90 (2): 215223 . 